\title{
Reproductive strategy of the common star fish, Astropecten polyacanthus (Echinodermata: Asteroidea) from Suez Canal Lakes, Egypt
}

\author{
Ahemd M. Hellal ${ }^{1}$; Ali A-F. Gab-Alla ${ }^{2}$; Saad Z. Mohamed ${ }^{2}$ \\ and Nesreen K. Morsy ${ }^{2}$ \\ 1: Marine Biology Section, Zoology Department, Faculty of Science, Al-Azhar University, \\ Nasr City, Cairo, Egypt. \\ 2: Marine Biology Department, faculty of Science, Suez Canal University, Ismailia, Egypt.
}

\section{ABSTRACT}

Specimens of the star fish, Astropecten polyacanthus were collected monthly from the Great Bitter lakes and Lake Timsah during the period from1999 to 2001. Individuals of $A$. polyacanthus showed a sex ratio (males to females) of 1:1.34 and 1:0.97 in Great Bitter lakes and Lake Timsah respectively. The examination of reproductive data showed that individuals of $A$. polyacanthus spawned all the year around with peaks during spring and autumn. Oocyte size frequency distribution was similar in both lakes and the egg size ranged from $8 \mu$ to $90 \mu$. All different sizes of oocytes were found all the year around with different proportions. Maximum fecundity (oocytes / female) reached 4800000 at Great Bitter Lakes and 7465860 at Lake Timsah. Fecundity showed exponential increases with the increase in body size, body weight and gonad weight.

Keywords: Astropecten polyacanthus, gonad index, sex ratio, fecundity

\section{INTRODUCION}

Echinoderms are important constituents of the near-shore marine biota, contributing significantly to the food chain and to the modification of the substrate (Lawrence, 1975). Although Suez Canal system is considered to be very important water body, almost no studies were so far carried out on its echinoderm fauna especially the biology of this group of animals. A. polyacanthus is a conspicuous asteroid and has a worldwide distribution and is capable of exploiting the different ecological niches of many coastal waters (Hellal, 1995 and Hasan, 1995).

In the study of reproductive biology of marine animals, three aspets may be recognized, mode (sexuality), machinery (structure), metabolic and behavioral organization and dynamics (temporal pattern and magnitude of energy development) (Fouda, 1990). The reproductive biology of sea stars from a wide variety of ecological niches has been examined by many authors (Nojima, 1981, 1982, 1983; Pearse et al., 1986; Komatsu et al., 1990; Chen and Chen, 1992; Byrne, 1992 and George, 1994 a \& b; Diaz-Guisalo et al., 2006; Raymond et al., 2007; Borrios et al., 2008). Many investigators considered that gonadal indices and their changes over time have been used as indicators of reproductive cycle for many species of marine animals (Schoenmakers et al., 1983; Azab, 1989; El-Sayed, 1992 and Hasan, 1995). However, the increase in gonado-somatic index during the period of gonadal maturation is mainly due to deposition of large amounts of protein and lipids in the developing eggs and spermatozoa (Thompson, 1982; McEdward and Carson, 1987; George et al., 1991 and El-Sayed, 1992). The number, size and amount of organic material in the eggs have been used to evaluate adult fitness (George et al., 1991; Himmelman et al., 2005; Raymond et al., 2007). Egg size and number can vary with the nutritional history of the adult and food availability (Emlet et al., 1987), spawning state of 
individual(s) among a population /or different populations (McEdward and Carson, 1987; George et al., 1990, 1991 and George, 1994 a) and with the maternal fecundity, fertilization and larval viability (Gerorge, 1990 a \& b; Xu and Barker, 1990 a \& b and Hasan, 1995).

The present work aimed to spotlight on the reproductive strategy of the common starfish Astropecten polyacanthus inhabiting Suez Canal Lakes, Egypt.

\section{MATERIALS AND METHODS}

More than 20 specimens of starfish, Astropecten polyacanthsus, were collected monthly from The Great Bitter Lake and Lake Timsah during the period from 1999 to 2001 for reproductive studies. The collected specimens were injected by $10 \%$ formalin, kept in plastic jars containing seawater formalin and transported to the laboratory for some biological studies. The major radius "R" (arm length) and the minor radius " $\mathrm{r}$ " (disc diameter) of the monthly sampled specimens were measured in $\mathrm{mm}$ for each individual. In the laboratory each individual of starfish was wet weighed, dissected and the gonads were removed and then wet weighed again. A gonad smear for each specimen was examined under a light microscope to determine the sex and monthly sex ratio was calculated. A series of different sizes of sea stars (from small to large) was made and gonads were examined to determine the size at first maturity. Monthly gonado-somatic index (GSI) was calculated for both males and females from both lakes using the following formula:

$$
\text { Gonad index }=\frac{\text { Wet weight of gonad (g) }}{\text { Wet weight of sea star (g) }} \times 100
$$

The indices were expressed as monthly average and plotted graphically.

For each mature female, the oocyte diameter was measured (in $\mu$ ) using a micrometer scale. Regardless to the egg sizes, diameters of about 200 oocytes were measured randomly using Image Pro Software ver. 5. Monthly sizes of oocyte were divided into intervals and the number within each interval size class was counted and its percentage was calculated from the total. Oocyte size frequency distribution was determined and represented graphically.

For each female specimen, three small pieces (about $0.1 \mathrm{~g}$ ) from the anterior, posterior and the center of gonad ribbon were taken to determine fecundity. Each part was homogenized in $5 \mathrm{ml}$ saline solution. After homogenization, one $\mathrm{ml}$ of the homogenate was taken, placed on a slide and examined microscopically. The mature oocyte (ripening) regardless to their size were counted and repeated three times. Using back calculation, the oocyte number of $5 \mathrm{ml}$ solution was calculated as follows:

Total oocyte number (in $0.1 \mathrm{~g}$ ) = Oocyte number of one $\mathrm{ml} \mathrm{X} 5$.

The average number of oocytes in $0.1 \mathrm{~g}$ sample was counted, from which the total number of oocytes in the entire gonad was calculated by applying the following formula:

Total oocytes number $=\frac{\text { Egg number of sample } \mathrm{X} \text { total gonad weight }}{\text { Weight of sample }}$

From the above mentioned method, the absolute fecundity (number of ripe or mature ova) in the ovary prior to spawning of each female was determined and correlated with the body size (disc diameter "r"), body weight and ovary weight.

Different statistical analyses were applied when possible such as the mean, regression analysis, correlation coefficient " $r$ " and difference between two regressions "t" and Chi-square. 


\section{RESULTS}

\section{1- Gonad morphology and size at first maturity}

The reproductive system of Astropecten polyacanthus consists of ten separate ovaries /or testes, two in each arm. These are located in the coelomic cavity laterally in the proximal part of the arm, and orally from the pyloric caeca. At each proximal end each gonad is attached by mesenteries and the gono-duct to the inside of the lateral body wall near the interbrachial septum. After spawning, the ovaries/or testes are thin, short and shrunken, while during the period of gonad growth and before spawning, the gonads are conspicuously large and extending from the angle of the arm almost to its tip. The color of gonads in both sexes varied from pale white to dark orange in ripe animals. These colors were related at least partly to sex and stage of maturity of the animals. During the period of study, it was noticed that females were mature at smaller size than males. The disc diameters " $r$ " for smallest mature females was 6.4 and $11 \mathrm{~mm}$ from Great Bitter Lake and Lake Timsah respectively, where as the smallest mature males had 7.7 and $11.7 \mathrm{~mm}$ disc diameters from both lakes respectively.

\section{2- Sex ratio}

Generally, A. polyacanthus showed a sex ratio of 1.0:1.34 and 1.0:0.97 (males to females) for individuals from Great Bitter Lake and Lake Timsah respectively. At Great Bitter Lake, females markedly outnumbered males almost all the year around. The ratio varied from 1.0:0.5 in January to 1.0:2.1 in December (Table 1). In contrast, at Lake Timsah, males outnumbered females most of the year and particularly throughout the spawning season. The ratio showed great variation from month to another, where it varied from 1.0:0.4 in May to 1.0:1.9 in October. The sex ratio was significantly deviated from the expected ratio of 1:1 in Great Bitter Lake (Chi-square test $\left.\chi^{2}=6.36, \mathrm{P}>0.05\right)$, but non-significant for Lake Timsah's individuals $\left(\chi^{2}=0.038\right.$, $\mathrm{P}<0.05)$.

Table 1: Monthly variations in sex ratio of Astropecten polyacanthus from Great Bitter Lake and Lake Timsah (Males to Females).

\begin{tabular}{|c|c|c|}
\hline Month & Great Bitter Lake & Lake Timsah \\
\hline November & $1: 1.5$ & $1: 1.4$ \\
\hline December & $1: 2.1$ & $1: 1.5$ \\
\hline January & $1: 0.5$ & $1: 1.1$ \\
\hline February & $1: 1.0$ & $1: 0.8$ \\
\hline March & $1: 1.9$ & $1: 0.7$ \\
\hline April & $1: 1.6$ & $1: 1.2$ \\
\hline May & $1: 1.0$ & $1: 0.4$ \\
\hline June & $1: 0.8$ & $1: 0.5$ \\
\hline July & $1: 1.7$ & $1: 0.8$ \\
\hline August & $1: 1.4$ & $1: 0.7$ \\
\hline September & $1: 1.6$ & $1: 0.8$ \\
\hline October & $1: 1.7$ & $1: 1.9$ \\
\hline November & $1: 1.5$ & $1: 0.8$ \\
\hline December & $1: 0.5$ & $1: 0.97$ \\
\hline Average & $1: 1.34$ & \\
\hline
\end{tabular}

\section{3- Gonado-somatic index (G.S.I)}

Monthly variations in gonado-somatic index of $A$. polyacanthus from the two lakes are given in Tables (2 and 3 ) and Figs. (1 and 2). The data showed that 
individuals of $A$. polyacanthus in both lakes were synchronized in their reproductive activities and they had two definite breeding seasons in spring and autumn (Figs. 1 and 2). Individuals from Great Bitter Lakes showed marked differences in the gonadal indices.

Table 2: Monthly variations of gonado-somatic index of Astropecten polyacanthus from Great Bitter Lake.

\begin{tabular}{|l|c|c|c|c|}
\hline \multirow{2}{*}{ Month } & \multicolumn{2}{|c|}{ Male } & \multicolumn{2}{c|}{ Female } \\
\cline { 2 - 5 } & Range & Mean \pm SD & Range & Mean \pm SD \\
\hline November & $0.91-4.76$ & $1.96 \pm 1.66$ & $0.22-10.19$ & $2.30 \pm 2.66$ \\
\hline December & $1.51-10.39$ & $4.44 \pm 2.87$ & $0.18-16.74$ & $5.46 \pm 5.33$ \\
\hline January & $0.74-7.33$ & $3.29 \pm 2.34$ & $0.34-9.91$ & $4.16 \pm 3.36$ \\
\hline February & $0.70-6.43$ & $2.37 \pm 1.81$ & $0.11-17.51$ & $5.36 \pm 5.57$ \\
\hline March & $0.40-20.22$ & $6.86 \pm 5.79$ & $2.21-19.72$ & $6.52 \pm 4.64$ \\
\hline April & $0.32-10.81$ & $4.15 \pm 4.50$ & $0.32-19.49$ & $5.92 \pm 5.28$ \\
\hline May & $0.15-7.33$ & $3.99 \pm 2.57$ & $0.17-17.03$ & $4.87 \pm 5.06$ \\
\hline June & $0.18-9.30$ & $3.87 \pm 2.45$ & $0.39-11.32$ & $3.08 \pm 3.95$ \\
\hline July & $0.15-4.03$ & $1.89 \pm 1.45$ & $0.54-14.99$ & $3.75 \pm 3.76$ \\
\hline August & $0.60-6.49$ & $4.42 \pm 1.81$ & $3.43-12.90$ & $6.83 \pm 2.81$ \\
\hline September & $0.10-15.22$ & $8.03 \pm 3.98$ & $5.16-26.91$ & $14.41 \pm 6.02$ \\
\hline October & $1.94-2.33$ & $2.15 \pm 0.20$ & $0.47-12.96$ & $2.02 \pm 2.63$ \\
\hline November & $0.11-7.56$ & $2.76 \pm 2.84$ & $0.28-18.54$ & $4.11 \pm 4.95$ \\
\hline December & $0.26-9.59$ & $4.84 \pm 2.77$ & $1.05-18.83$ & $8.41 \pm 6.22$ \\
\hline
\end{tabular}

Table 3: Monthly variations of gonado-somatic index of Astropecten polyacanthus from Lake Timsah.

\begin{tabular}{|l|c|c|c|c|}
\hline \multirow{2}{*}{ Month } & \multicolumn{2}{|c|}{ Male } & \multicolumn{2}{c|}{ Female } \\
\cline { 2 - 5 } & Range & Mean \pm SD & Range & Mean \pm SD \\
\hline November & $0.64-32.26$ & $7.28 \pm 10.70$ & $0.22-30.50$ & $9.56 \pm 9.29$ \\
\hline December & $0.47-2.33$ & $1.29 \pm 0.76$ & $0.19-4.34$ & $1.29 \pm 1.28$ \\
\hline January & $0.86-5.21$ & $2.68 \pm 1.69$ & $0.82-9.18$ & $3.88 \pm 2.49$ \\
\hline February & $1.56-7.74$ & $3.81 \pm 2.10$ & $0.60-13.12$ & $5.35 \pm 4.02$ \\
\hline March & $0.54-32.37$ & $6.18 \pm 8.85$ & $0.39-13.88$ & $4.13 \pm 4.60$ \\
\hline April & $1.00-16.49$ & $9.16 \pm 5.27$ & $0.45-13.73$ & $5.17 \pm 5.15$ \\
\hline May & $2.07-9.29$ & $6.02 \pm 2.26$ & $1.06-6.67$ & $4.15 \pm 2.33$ \\
\hline June & $0.56-4.74$ & $1.90 \pm 1.44$ & $0.91-5.97$ & $2.60 \pm 1.96$ \\
\hline July & $0.62-3.90$ & $2.06 \pm 1.36$ & $0.49-2.78$ & $1.91 \pm 1.24$ \\
\hline August & $0.20-8.83$ & $4.86 \pm 3.07$ & $1.41-7.42$ & $3.73 \pm 2.35$ \\
\hline September & $0.36-6.87$ & $3.60 \pm 1.76$ & $0.47-13.35$ & $6.75 \pm 4.80$ \\
\hline October & $0.54-11.42$ & $3.68 \pm 4.11$ & $0.17-13.05$ & $3.85 \pm 3.69$ \\
\hline November & $0.26-12.57$ & $5.82 \pm 4.66$ & $0.85-7.13$ & $4.00 \pm 2.74$ \\
\hline
\end{tabular}


These indices ranged from 0.11 in February to 26.91 in September for females and the highest mean values of the G.S.I were recorded in March $(6.52 \pm 4.64)$ and September $(14.41 \pm 6.02)$ and the lowest mean of G.S.I was observed in October $(2.02 \pm 2.63)$. On the other hand, males from the same lakes exhibited a similar pattern to that observed for females. The highest mean values of the G.S.I were recorded in March $(6.86 \pm 5.79)$ and September $(8.03 \pm 3.98)$, while the Minimum G.S.I mean values were recorded in November $(1.96 \pm 1.66)$ and July $(1.89 \pm 1.45)$. At the end of each spawning season the collected individuals of both sexes have relatively low G.S.I (Table, 2 and Fig. 1).

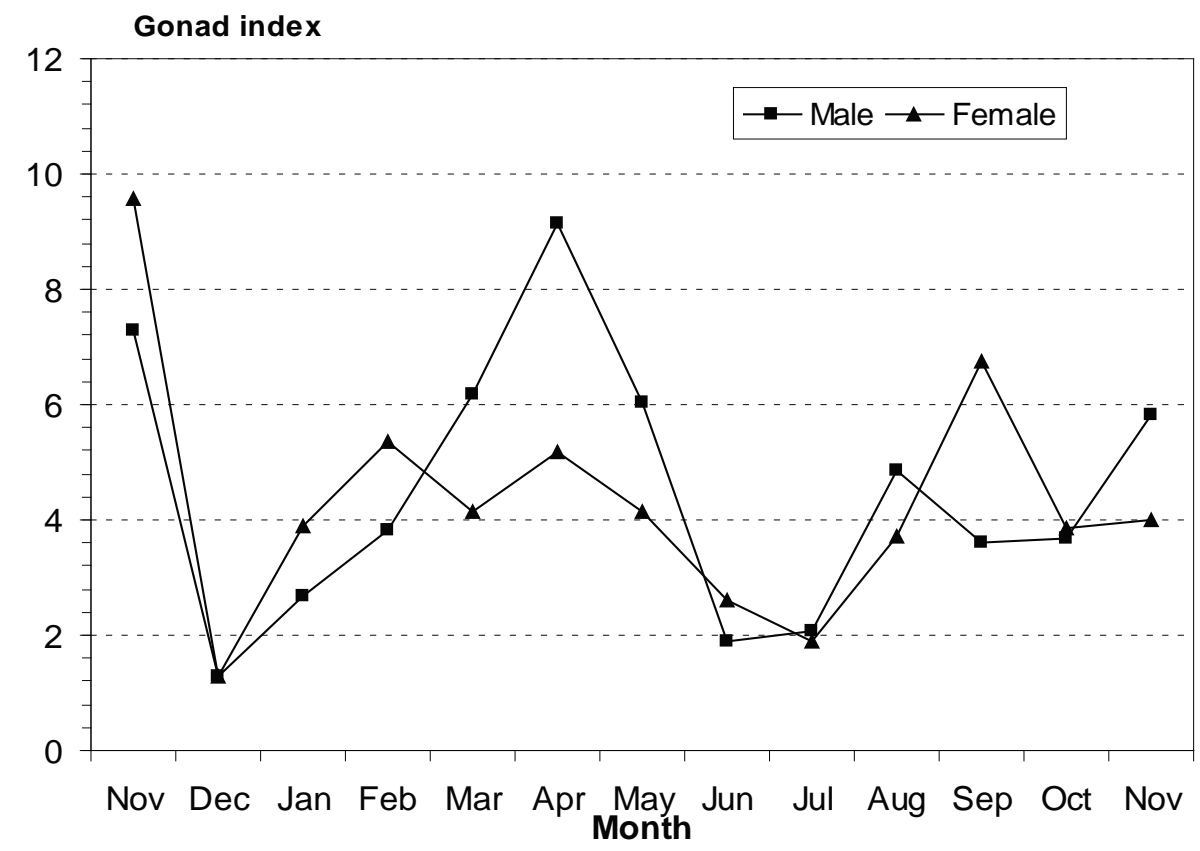

Fig. 1: Monthly variations of gonado-somatic index of A. polyacanthus from Great Bitter Lake.

Gonad index

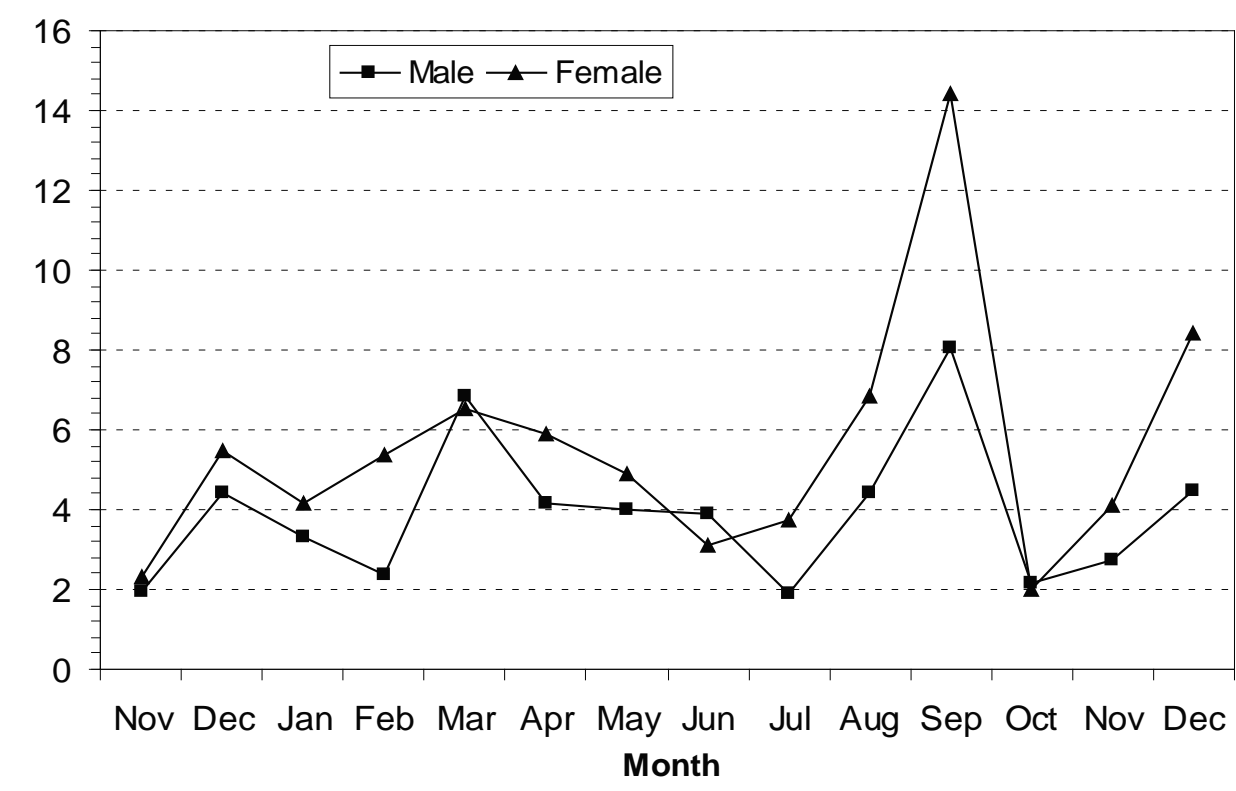

Fig. 2: Monthly variations of gonado-somatic index of A. polyacanthus from Lake Timsah 
At Lake Timsah, individuals exhibited a wide range in their G.S.I. The indices varied from 0.17 in October to 30.5 in November for females and from 0.20 in August to 32.37 in March for males (Table 3). The average of G.S.I for females showed monthly fluctuations with three peaks in November $(9.56 \pm 9.29)$, February $(5.35 \pm$ 4.02) and September $(6.75 \pm 4.80)$ and the minimal average value was recorded in December $(1.29 \pm 1.28)$, whereas, the highest means of G.S.I were recorded in November (7.28 \pm 10.17$)$ and April $(9.16 \pm 5.27)$ for males and the minimum values were observed in December $(1.29 \pm 0.76)$ and June $(1.90 \pm 1.44)$ (Table 3 and Fig. 2$)$.

\section{4- Oocyte-size frequency distribution}

Oocyte frequency distribution of $A$. polyacanthus from both lakes is represented in Table (4) and Figs. (3 and 4). In all collected females, mature and immature gametes could be found altogether and a synchrony among individuals was also found in oocyte growth. The size of oocytes ranged between $8 \mu$ and $90 \mu$ in both lakes, and the all sizes of oocytes were found all the year round but with different proportions (Table, 4). No sequence of oocytes growth could be detected throughout the year. However, in Lake Timsah, a predominance of small oocytes (less than $40 \mu$ diameter) occurred in December (88.1 \%) and July (87.5 \%). The samples taken during the following months (January- March) had a large proportion of medium sized oocytes (40 $\mu$ to $60 \mu$ ), indicating their growing up to become large oocytes. During the first spawning season (spring) the sample taken had a large proportion of mature oocytes $(>60 \mu)$. During June-July (resting period) the ovaries dominated by great number of small oocytes, being $76.1 \%$ and $87.5 \%$ respectively (Table, 4). During the following months, these oocytes grew to medium size then to mature oocytes where the second spawning season (autumn month) starts (Fig. 4).

Table 4: Monthly variations of oocytes size $(\mu)$ of Astropecten polyacanthus from Great Bitter Lake and Lake Timsah (data represented as a percentage).

\begin{tabular}{|l|c|c|c|c|c|c|}
\hline \multirow{3}{*}{ Month } & \multicolumn{3}{|c|}{ Great Bitter Lake } & \multicolumn{3}{c|}{ Lake Timsah } \\
\cline { 2 - 7 } & small size & Medium size & Large size & small size & Medium size & Large size \\
\cline { 2 - 7 } & $0-40$ & $40-60$ & $<60$ & $0-40$ & $40-60$ & $<60$ \\
\hline November & 69.8 & 17.7 & 12.5 & 11.6 & 52.5 & 35.9 \\
\hline December & 32.2 & 26.5 & 41.3 & 88.1 & 6.6 & 5.3 \\
\hline January & 41.2 & 26.3 & 32.5 & 48.9 & 30.1 & 21.0 \\
\hline February & 44.3 & 44.7 & 11.0 & 25.6 & 50.4 & 24.0 \\
\hline March & 14.9 & 62.0 & 23.1 & 20.1 & 57.7 & 22.2 \\
\hline April & 19.5 & 44.9 & 35.6 & 49.3 & 32.9 & 17.8 \\
\hline May & 44.7 & 29.2 & 26.1 & 20.0 & 51.0 & 29.0 \\
\hline June & 51.2 & 22.8 & 26.0 & 76.1 & 13.1 & 10.8 \\
\hline July & 55.5 & 23.3 & 21.2 & 87.5 & 10.8 & 1.7 \\
\hline August & 13.6 & 71.4 & 15.0 & 35.6 & 47.1 & 17.3 \\
\hline September & 3.5 & 63.6 & 32.9 & 31.4 & 48.6 & 20.0 \\
\hline October & 78.8 & 16.1 & 5.1 & 51.6 & 23.4 & 25.0 \\
\hline November & 60.9 & 30.7 & 8.4 & 37.6 & 52.5 & 9.9 \\
\hline December & 37.9 & 45.8 & 16.3 & ----- & ----- & ---- \\
\hline
\end{tabular}

In Great Bitter Lake, the oocyte-size distribution exhibited the same pattern in Lake Timsah. The largest amount of small oocytes occurred during two months prior to the spawning season, for instance, it was represented by $44.3 \%$ in February and $55.5 \%$ in July. However, the medium size and mature oocytes occurred in a high proportion at the beginning and even throughout the spawning seasons (Table, 4 and Fig. 3). The presence of large oocytes with low percentages in December (5.3\%) and July (1.7 \%) for Lake Timsah's individuals and in October (5.1\%) for Great Bitter 
Lake's samples reflected the end of spawning season. This was supported by the presence of small oocytes with very high frequencies in the individuals from both lakes (Table, 4).

\section{5- Fecundity}

Fecundity is defined as number of mature oocytes per female. Mature oocytes are stored in the lumen of ovary's acini till spawning occurs. The large oocytes are found at the centre of lumen, whereas the small ones are found near the periphery of acini. At Great Bitter Lake, the fecundity of collected females (158 individuals) varied between 7,260 oocytes in July and 4,800,000 oocyte in November. Although individuals exhibited a wide range in their fecundity, the average fecundity showed a marked monthly fluctuation. The highest average of fecundity was recorded in November, being 1,691,787 oocyte, whereas the lowest average $(122,290)$ was recorded in October (Table, 5). At Lake Timsah, the fecundity of examined females (101 individuals) ranged between 20,580 in March and 7,465,860 oocyte in December. The monthly average fecundity fluctuated from month to another, the highest average fecundity occurred in December, being 2,731,400 oocyte, while the lowest average (401,675 oocyte) was observed in March (Table, 5).

Table 5: Monthly variations of fecundity of Astropecten polyacanthus from Great Bitter Lake and Lake Timsah.

\begin{tabular}{|l|c|c|c|c|}
\hline \multirow{2}{*}{ Month } & \multicolumn{2}{|c|}{ Great Bitter Lake } & \multicolumn{2}{c|}{ Lake Timsah } \\
\cline { 2 - 5 } & Range & Mean \pm SD & Range & Mean \pm SD \\
\hline November & $8160-1062810$ & $498824.0 \pm 362563.3$ & $1108360-4298400$ & $2019993.0 \pm 1041308.7$ \\
\hline December & $258500-3125820$ & $1044717.9 \pm 817255.9$ & $351670-7465860$ & $2731400.0 \pm 2861166.6$ \\
\hline January & $44730-970020$ & $496886.3 \pm 379718.7$ & $75330-6937816$ & $1621006.1 \pm 1747597.7$ \\
\hline February & $46080-2290420$ & $762700.0 \pm 875588.4$ & $68020-2508300$ & $1046188.0 \pm 787231.1$ \\
\hline March & $197160-1597970$ & $715821.3 \pm 458099.7$ & $20580-1260875$ & $401675.0 \pm 397095.2$ \\
\hline April & $97300-844830$ & $385624.4 \pm 288851.2$ & $46110-1602000$ & $647853.1 \pm 619530.9$ \\
\hline May & $145200-1388070$ & $459508.0 \pm 398584.0$ & $74580-1391200$ & $558575.7 \pm 453322.2$ \\
\hline June & $47250-641500$ & $253971.4 \pm 202318.7$ & $138510-2037000$ & $1061037.5 \pm 866364.9$ \\
\hline July & $7260-309680$ & $149838.9 \pm 92956.7$ & $1523800-1635900$ & $1579850.0 \pm 79266.7$ \\
\hline August & $107500-786130$ & $368726.9 \pm 176022.3$ & $328525-1536435$ & $711989.0 \pm 474878.2$ \\
\hline September & $109260-1472640$ & $812543.9 \pm 354977.8$ & $77470-390390$ & $188172.0 \pm 89416.6$ \\
\hline October & $44175-237600$ & $122290.6 \pm 68816.3$ & $61820-1863325$ & $640770.8 \pm 627666.6$ \\
\hline November & $351900-4800000$ & $1691787 \pm 1640552.3$ & $91350-784220$ & $421617.5 \pm 269311.9$ \\
\hline December & $244860-2913265$ & $1598697.9 \pm 970545.5$ & -------- & ------ \\
\hline
\end{tabular}

\section{6- Relationship between fecundity and body size, body weight and ovary weight}

In both lakes, the fecundity of $A$. polyacanthus increases with increasing of body weight (Fig. 5). The variation in oocyte number within the same body weight is due to the differences in the degree of ripeness of the starfish. The curvilinear relationships were fitted between the body weight and fecundity (Fig. 5). The data representing the relationships between fecundity and body size of A. polyacanthus from Great Bitter Lake and Lake Timsah are given in Fig. (6). It is clear that the fecundity increases with increasing of body size. The curvilinear relationships were found to be highly significant in both lakes. Also, the fecundity increases with increasing the ovary weight for both lakes (Fig. 7). The curvilinear relationships showed no significant differences in slope values between the two lakes. 

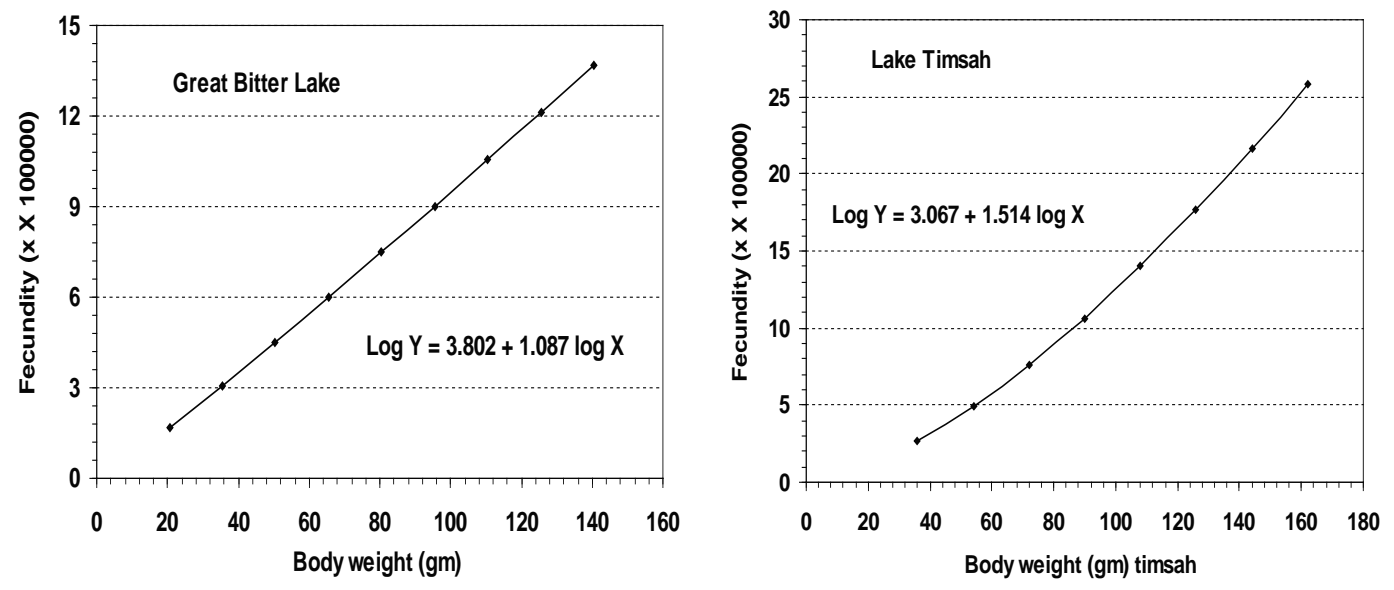

Fig. 5: Relationship between fecundity and body weight of A. polyacanthus from Suez Canal Lakes.
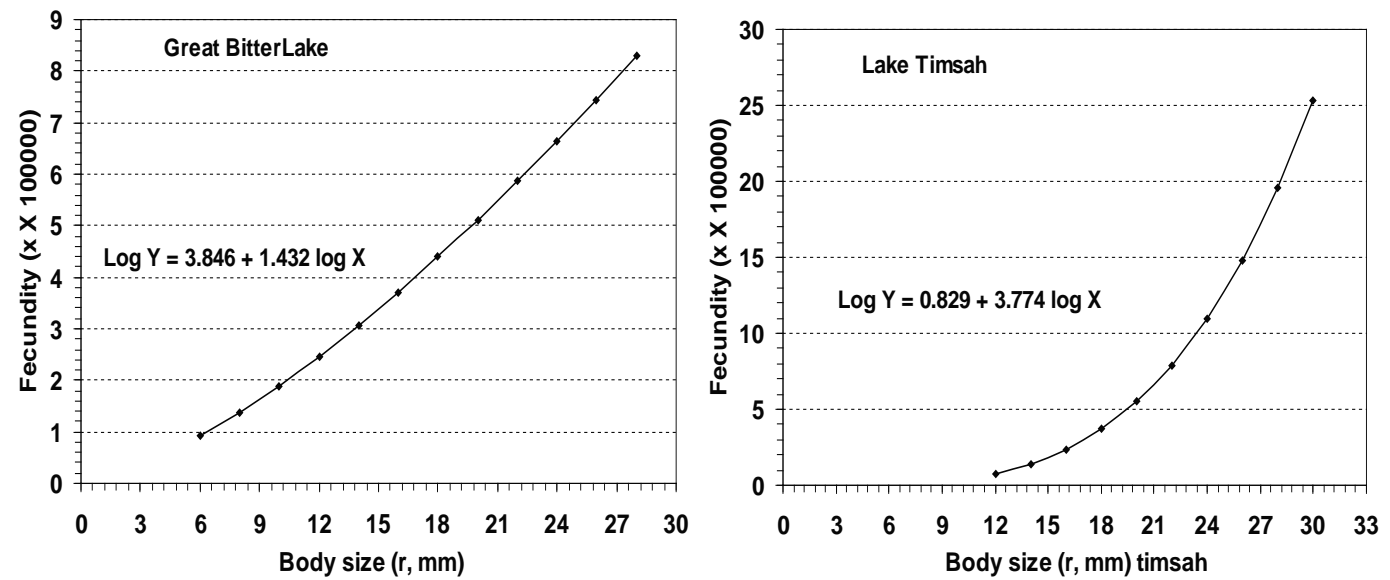

Fig. 6: Relationship between fecundity and body size of A. polyacanthus from Suez Canal lakes.
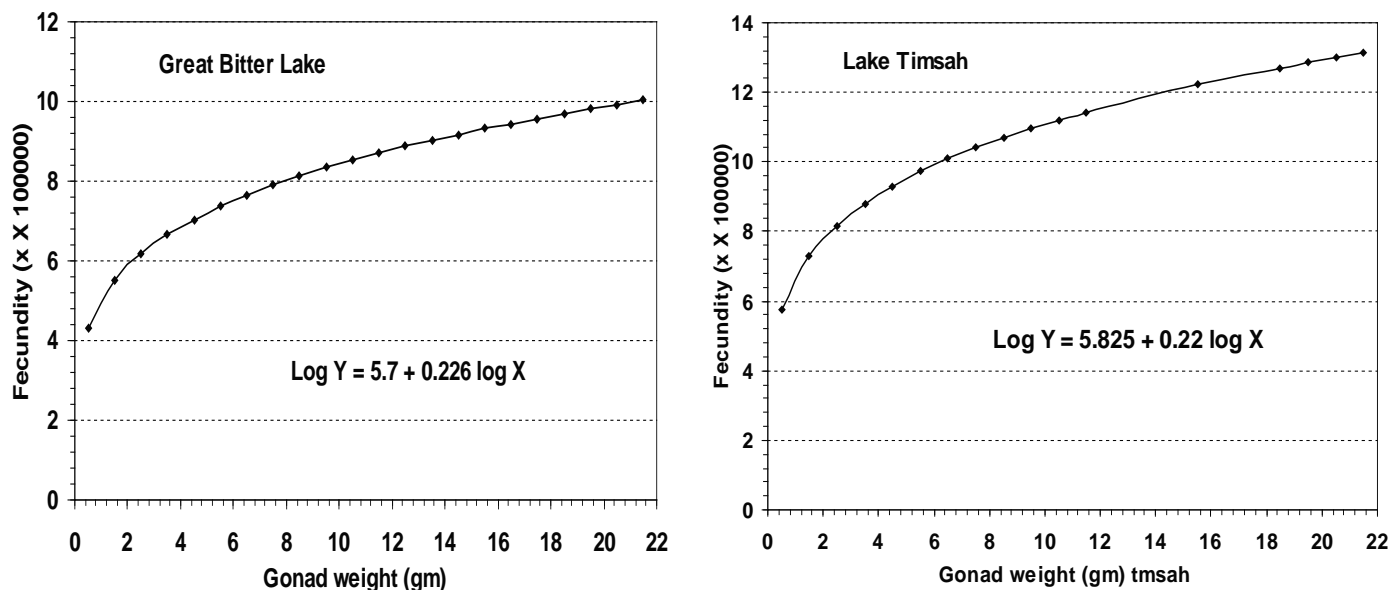

Fig. 7: Relationship between fecundity and gonad weight of A. polyacanthus from Suez Canal lakes.

\section{DISCUSSION}

In the present study, it was found that females out numbered males almost all the year round with a sex ratio of 1:1.34 (males to females) $\left(\chi^{2}=6.36, \mathrm{P}>0.05\right)$ for the Great Bitter Lake population. In contrast to this ratio, 1:0.79 was reported for 
Timsah Lake population. However, this species seems have no habit of sex reversal unlike other asteroid species such as Asterina gibbosa (Brusle, 1969), Nepanthia belcheri and Fromia ghardaqana (Mortensen, 1938). Also, the results showed that this ratio was not constant throughout the year even during the breeding season. The reason for such ratio may be explained by differential mortality (Nojima 1979, 1983), migration to deep water (Nunomura and Nambu, 1981and Nojima, 1983), habitat selection (Oguro et al., 1981) and restricted nutrition (Bak and Nojima, 1980; Sloan and Aldridge, 1981 and Cobb and Caddy, 1989; Gaymer et al., 2004).

According to Thorson (1936, 1946 and 1950) and Nojima (1979) Astropecten polyacanthus under investigation appears to belong to group (1) which shed their sexual products freely in water and has small eggs and planktonic larvae. Gonadal indices and their changes over time have been used as indicators of reproductive cycle for many species of marine animals (Schoenmakers et al,. 1983; Azab, 1989; ElSayed, 1992; Hasan, 1995 and Royer et al., 2008). The increase in gonado-somatic index during the period of gonad maturation is mainly due to deposition of large amount of proteins and lipids in the developing eggs and spermatozoa (Thompson, 1982; Emlet et al., 1987; McEdward and Carson, 1987 and George et al., 1991). Part of these materials comes directly from ingested food but a major proportion comes from reserves of food deposits during the active feeding period in the nutritive cells in the gonads. It is therefore reasonable to expect that the weight of gonads would reflect the accumulation and utilization of these energy reserves (Fouda, 1990 and El-Sayed, 1992). Although a number of species seem to reproduce throughout the year, many species have periodic seasonal breeding pattern (Pearse, 1968 and Pearse and Barksdale, 1986). Concerning stages of sexual maturity, gonadal indices, pyloric caeca indices, oocyte size frequency distribution and fecundity, as well as the appearance of young individuals, A. polyacanthus has an extended spawning season during the whole year with definite two peaks, one occurs during spring and beginning of summer and the second one occurs during autumn. These findings are more or less similar to the results on Astropecten latespinosus from different localities elsewhere (Nojima, 1979, 1981, 1982 and 1983) and of Patiriella pseudoexigua from Taiwan (Chen and Chen, 1992). However, other asteroid species spawn during summer season such as Marthasterias glacialis (Minchin, 1987), Asterina pseudoexigua (Komatsu et al., 1990) and Asterias vulgaris (Raymond et al., 2007).

The differences in the mean gonadal index from place to place may reflect either difference in the individual gonad growth or in the degree of synchronization of gonadal development in the population (McPherson, 1969). The present study indicated that individuals of $A$. polyacanthus had well synchronized spawning with two definite peaks. The same results were achieved by Chen and Chen (1992 and 1993) for the sea star, Patiriella pseudoexigua from Taiwan; Byrne (1992) for Patiriella gunni, P. calcar and P. exigua from New South Wales and Crump (1971) for Patiriella regularis from New Zealand.

The number, size and amount of organic material in the eggs have been used to evaluate adult fitness (George et al., 1991; Raymond et al., 2007). However, Emlet et al., (1987) and Gaymer et al. (2004) indicated that the reproductive output differs in relation to food availability for echinoderms. Egg size and organic content of eggs varies not only within a single spawn of a single individual, but among individuals from the same population or from different populations and over time (Emlet et al., 1987; McEdward and Carson, 1987; George, 1990 a \& b, 1994 a \& b and George et al., 1990, 1991, 2006; Raymond et al., 2007). These variations have been attributed to variations in food supply. Inadequate diet adversely affects on maternal fecundity, 
fertilization and larval viability (George, 1990 a \& b; Borrios et al., 2008). Analysis of diet composition of $A$. polyacanthus from both lakes showed that the diet of this species was almost the same with differences in the proportion of each food item (Hellal et al., 2009). Also, in the present study, the egg size varied from 8 to $90 \mu$ with monthly fluctuations in the proportions of the egg size. These data indicated that egg size in A. polyacanthus is not greatly affected by food, so the egg size is not a good indicator of egg quality for this species. This is in full agreement with the results obtained by George et al., (1991) for sea star, Luidia clathrat. Similarly, Xu and Barker (1990 a \& b) reported no significant difference in egg size in both fed or starved individuals of Sclerasterias mollis. Also Thompson (1982) found the same results for the sea urchin, Strongylocentrotus droebachiensis.

More recent models on the reproductive strategies incorporate larval dispersion and larval mortality (Winkler and Wallin, 1987), parental care (Sargent et al., 1987), female nutritional state and female size (Venable, 1992 and George, 1994 a \& b), egg size and mode of larval nutrition (Vance, 1973) and the effect of environmental variation on offspring investment (Kaplan and Cooper, 1984; Gaymer et al., 2004). In the present study, females of $A$. polyacanthus from both lakes produce large numbers of small eggs (up to $90 \mu$ ) (Tables, 4 and5). Such findings are agreed with the life history model by Roff (1992) which predicts that females should produce more but small eggs in favorable environmental conditions. The nutritional state of females, the size of females and parental care are also incorporated with the amount of produced eggs (Venable, 1992). These reflect the contrdicton between small eggs / feeding larvae and large eggs / non feeding larvae models of development. Putting the above facts in to consideration, it is clear that $A$. polyacanthus complies well with the Vance's models (1973).

\section{REFERENCES}

Azab, A.M. (1989): Ecological and biological studies on some fishes (Cyprinodontidae) living in waters of different salinities (Euryhaline fishes). M.Sc. Thesis. Al-Azhar Univ. 226 pp.

Bak, H.P. and Nojima, S. (1980): Immigration of tropical sea urchin, Astropyga radiata (Leske) in a temperate eelgrass, Zostera marina L. patch: Its feeding habit and grazing effect on patch. Publ. Amakusa,Mar. Biol. Lab. 5: 153- 169.

Borrios, J.V.; Gaymer, C.F.; Julio, A.V. and Katherina, A.B. (2008): Effect of the degree of autotomy on feeding, growth, and reproductive capacity in the multiarmed sea star Heliaster helianthus. J. Exp. Mar. Biol. Ecol. 361 (1): 21 - 27.

Brusle, J. (1969): Les cycles geniteaux d' Asterina gibbosa. P.Cah. Biol. Mar. 10: 271 $-287$.

Byrne, M. (1992): Reroductive of sympatric populations of Patiriella gunni, P. calcar and $P$. exigua in New Souoh Wales, asterinid sea stars with direct development. Mar. Biol. 114 (2): 297 - 316.

Chen, B.Y. and Chen, C.P. (1992): Reproductive cycle, larval development, juvenile growth and population dynamics of Patiriella pseudoexigua (Echinodermata: Asteroidea) in Taiwan. Mar. Biol. 113 (2): 271 - 280.

Chen, B.Y. and Chen, C.P. (1993): The effect of temperature-salinity combinations on survival and growth of juvenile Patiriella pseudoexigua (Echinodermata: Asteroidea) in Taiwan. Mar. Biol. 113(2): 271 - 280. 
Cobb, J.S. and Caddy, J.F. (1989): The population biology of decapods. In: Marine invertebrates fisheries their assessment and management. (Caddy, J.F., ed.). 327 $-373$.

Crump, R.G. (1971). Annual reproductive cycles in three geographically separated populations of Patiriella regularis (Verrill), a common New Zealand asteroid. J. Exp. Mar. Biol. Ecol. 7: 137 - 162.

Diaz-Guisado, D. Gaymer, C.F.; Brokordt, K.B. and lawerence, .M. (2006): Autotomy reduces feeding, energy storage and growth of the sea star Stichaster striatus. J. Exp. Mar. Biol. Ecol. 338 (1): 73 - 80.

El-Sayed, A.A.M. (1992): Biological studies on some brachyuran crabs (Crustacea) from Suez Canal. Ph.D. Thesis. Zool. Dept. Fac. Sci. Al-Azhar Univ.

Emlet, R.B.; McEdward, L.R. and Strathmann, R.R. (1987): Echinodermal larval ecology viewed from the egg. In: Echinoderm Studies, (Jangoux, M. and Lawrence, J.M., eds.) 55 - 136. Balkema, A.A.,Rotterdam.

Fouda, M.M. (1990): Biological and physiological studies on goby fishes from Timsah Lake. Ph.D. Thesis. Zool. Dept. Girl Collage, Ain Shams Univ.

Gaymer, C.F.; Dutil, C. and Himmelman, J.H. (2004): Prey selection and predatory impact of four major sea stars on a soft bottom subtidal community. J. Exp. Mar. Biol. Ecol. 313 (2): 353-374.

George, B.S. (1990 a): Responses reproductives de trios echinoderms en relation avec la nourriture et les consequences sur le development larvaire. These de Doctorat de l'Universite paris.

George, B.S. (1990 b): Population and seasonal differences in egg quality of Arbacia lixula (Echinodermata: Echinoidea). Invert. Reprod. Dev. 17: 111 - 121.

George, B.S. (1994 a): The Leptasterias (Echinodermata: Asteroidea) species complex: variation in reproductive investment. Mar. Ecol. Prog. Ser. 109: 95 98.

George, B.S. (1994 b): population differences in maternal size and offspring quality for Leptasterias epichlora (Brandt) (Echinodermata: Echinoidea). J. Exp. Mar. Biol. Ecol. 175: 121 - 131.

George, B.S.; Cellario, C. and Fenaux, L. (1990): Population differences in egg quality of Arbacia lixula (Echinodermata: Echinoidea): Proximate composition of eggs and larval development. J. Exp. Mar. Biol. Ecol. 141: 107 - 118.

George, B.S.; Lawrence, J.M. and Fenaux, L. (1991): The effect of food ration on the quality of eggs of Luidia clatharata (Say) (Echinodermata: Asteroidea). Invert. Reprod. Dev. 20: 237 - 242.

George, E.T.; Termara, A. and Holdway,D.A. (2006): The reproductive cycle of the asteroid Coscinasterias muricata in Port Phillip Bay, Victoria, Australia. J. Exp. Mar. Boil. Ecol. 332: 188 - 197.

Hasan, M.H. (1995): Ecological and biological studies on echinoderms from the Gulf of Suez, Red Sea. M. Sc. Thesis, Mar. Biol. Dept. Fac. Sci. Suez Canal Univ.

Hellal, A.M. (1995): Key to the star fishes (Echinodermata: Asteroidea) from the Red Sea. J. Fac. Educ. Ain Shams Univ. 20: 591 - 610.

Hellal, A.M.; Ali A-F. Gab-Alla, A.F.; Mohamed, S.Z. and Morsy, N.K. (2009): Some biological aspects of the common star fish, Astropecten polyacanthus (Echinodermata: Asteroidea) from Suez Canal Lakes, Egypt. $1^{\text {st }}$ Symposium of Ecology, Fac. Sci. Thamar Univ. Yemen, 18-19 March, 2009.

Himmelman, J.H.; Dutil, C. and Gaymer, C.F. (2005): Foraging behavior and activity budgets of sea stars on a subtidal sediment bottom community. J. Exp. Mar. Biol. Ecol. 332 (2): 153 - 165. 
Kaplan, R.H. and Cooper, W.S. (1984): The evolution of developmental plasticity in reproductive characteristics. An application of the adaptive coin flipping principle. Amm. Nat. 123: 393 - 410.

Komatsu, M.; Kano, Y.T. and Oguro, C. (1990): Development of a true ovoviviparous sea star, Asterina pseudoexigua pacifica Hayashi. Biol. Bull. 179 (3): 254 - 263.

Lawrence, J.M. (1975): On the relationship between marine plants and sea urchins. Oceanogr. Mar. Biol. Annu. Rev. 13: 213 - 286.

McEdward, L.R. and Carson, F. (1987): Variation in egg organic content and its relationship with egg size in the starfish Solaster stimpsoni. Mar. Ecol. Prog. Ser. 37: 159-169.

McPherson, B.F. (1969): Studies on the biology of the tropical sea urchins, Echinometra lucunter and Echinometra viridis. Bull. Mar. Sci. 19: 194 - 213.

Minchin, D. (1987): Sea water temperature and spawning behavior in the sea star, Marthasterias glacialis. Mar. Biol. 95: 139 - 143.

Mortensen, T. (1938): Contribution to the study of development and larval forms of echinoderms. IV. K. Danske Vidensk. Skr. (Naturv. Math.). 9: 1- 59.

Nojima, S. (1979): Ecological studies of a sea star, Astropecten latespinosus Meissner. I. Survivorship curve and life history. Publ. Amakusa Mar. Biol. Lab. 5: $54-65$.

Nojima, S. (1981): Ecological studies of a sea star, Astropecten latespinosus Meissner. II. Growth rate and differences in growth pattern of immature and mature sea stars. Publ. Amakusa Mar. Biol. Lab. 6: 65 - 84.

Nojima, S. (1982): Ecological studies of the sea star Astropecten latespinosus Meissner. IV. Growth curve. Publ. Amakusa Mar. Biol. Lab. 6 (2): 85 - 94.

Nojima, S. (1983): Ecological studies of the sea star Astropecten latespinosus Meissner. V. Pattern of spatial distribution and seasonal migration, with special reference to spawning aggregation. Publ. Amakusa Mar. Biol. Lab. 7 (1): 1 - 16.

Nunomura, N. and Nambu, H. (1981): Shore fauna of Hamakurosaki beach, Toyama City, 1978-1980. Bull. Toyama SXI. Mus. 3: 25 - 37.

Oguro, C.; Komatsu, M. and Kano, Y.T. (1981): A note on the early development of Astropecten polyacanthus Muller et Troschel. Proc. Jap. Soc. Syst. Zool. 11: 49 $-52$.

Pearse, J.S. (1968): Patterns of reproductive periodicities in four species of IndoPacific echinoderms. Proc. Ind. Acad. Sci. 67: 247 -279.

Pearse, J.S. and Barkasdale, M.J. (1986): Temporal patterns of reproduction by shallow water invertebrates in the Indian Ocean. In: Biology of benthic marine organisms (Thompson, M,F.;Sarojini, R. and Nagbushanan,R. eds.). Oxford and IHB publishing company, New Dehi, Bombay, Calcutta.

Pearse, J.S.; Bosch, I.; McClintock. J.B. and Brunton, R. (1986): Contrasting tempos of reproduction of shallow water animals in McMurdo Sound. Antarctica. Antarctic, J.U.S. 221- 234.

Raymond, J.F.; Himmelman, J.H. and Guderley, H.E. (2007): Biochemical content, energy composition and reproductive effort in the broadcasting sea star Asterias vulgaris over the spawning period. J. Exp. Mar. Biol. Ecol. 341 (1): 32 - 44

Roff, D.A. (1992): The evolution of life histories theory and analysis.Chapman and Hall, New York 535 pp.

Royer, J.; Seguineau, C.; Kyung, P.; Purveau, S.; Choi, S. and Costil, K. (2008): Gametogenetic cycle and reproductive effort assessed by two methods in 3 age classes of Pacific oysters, Crassostrea gigas, reared in Normandy. Aquaculture. 277(3-4): 313 - 320. 
Sargent, R.C.; Taylor, P.D. and Gross, M.R. (1987): Parental care and the evolution of egg sizes in fishes. Am. Nat. 129: 32 - 46.

Schoenmakers, H.J.N.; Goedhart, M.J. and Voogt, P.A. (1983): Biometrical and histological aspects of the reproductive cycle of the ovaries of Aterias rubens (Echinodermata). Biol. Bull. 166: 328 - 348.

Sloan, N.A. and Aldridge, T.H. (1981): Observations on aggregation of the star fish Asterias rubbens L. in Morecambe Bay, Lancashire, England. J. Nat. Hist. 15: $407-418$.

Thompson, R.J. (1982): The relationship between food ration and reproductive effort in the green sea urchin, Strongylocerntrotus droebachiensis. Oecologia (Berlin). 56: $50-57$.

Thorson, G. (1936): The larval development, growth and metabolism of arctic marine bottom invertbrates. Medd. Gronland. 100 (6): 155.

Thorson, G. (1946): Reproduction and larval development of Danish marine bottom invertebrates. Medd.Komm. Havundersog. Kbh. Ser. Plankton. 4: 1 -523.

Thorson, G. (1950): Reproductive and larval ecology of marine bottom invertebrates. Biol. Rev. 25: 1 - 45.

Vance, R.R. (1973): On reproductive strategies in marine benthic invertebrates. Am. Nat. 107: 339 - 352.

Venable, D.W. (1992): Size-number trade-offs and the variation of seed size with plant resource status. Am. Nat. 140: 287 - 304.

Winkler, D. W. and Wallin, K. (1987): Offspring size and number: A life history model linking effort per offspring and total effort. Am. Nat. 129: 708 - 720.

Xu, R.A. and Barker, M.F. (1990 a): Laboratory experiments on the effect of diet on the gonad and pyloric caeca indices and biochemical composition of tissues of the New Zealand starfish, Sclerasterias mollis (Hutton) (Echinodermata: Asteroidea). J. Ex. Mar. Biol. Ecol. 136: 23 - 45.

Xu, R.A. and Barker, M.F. (1990 b): Effect of diet on steroid level and reproduction in the starfish Sclerasterias mollis. Comp. Biochem. Physiol. 96A: 3339. 


\begin{tabular}{|c|c|c|c|c|}
\hline \multicolumn{2}{|c|}{ November 1999} & \multicolumn{3}{c|}{ Percenta } \\
\hline
\end{tabular}




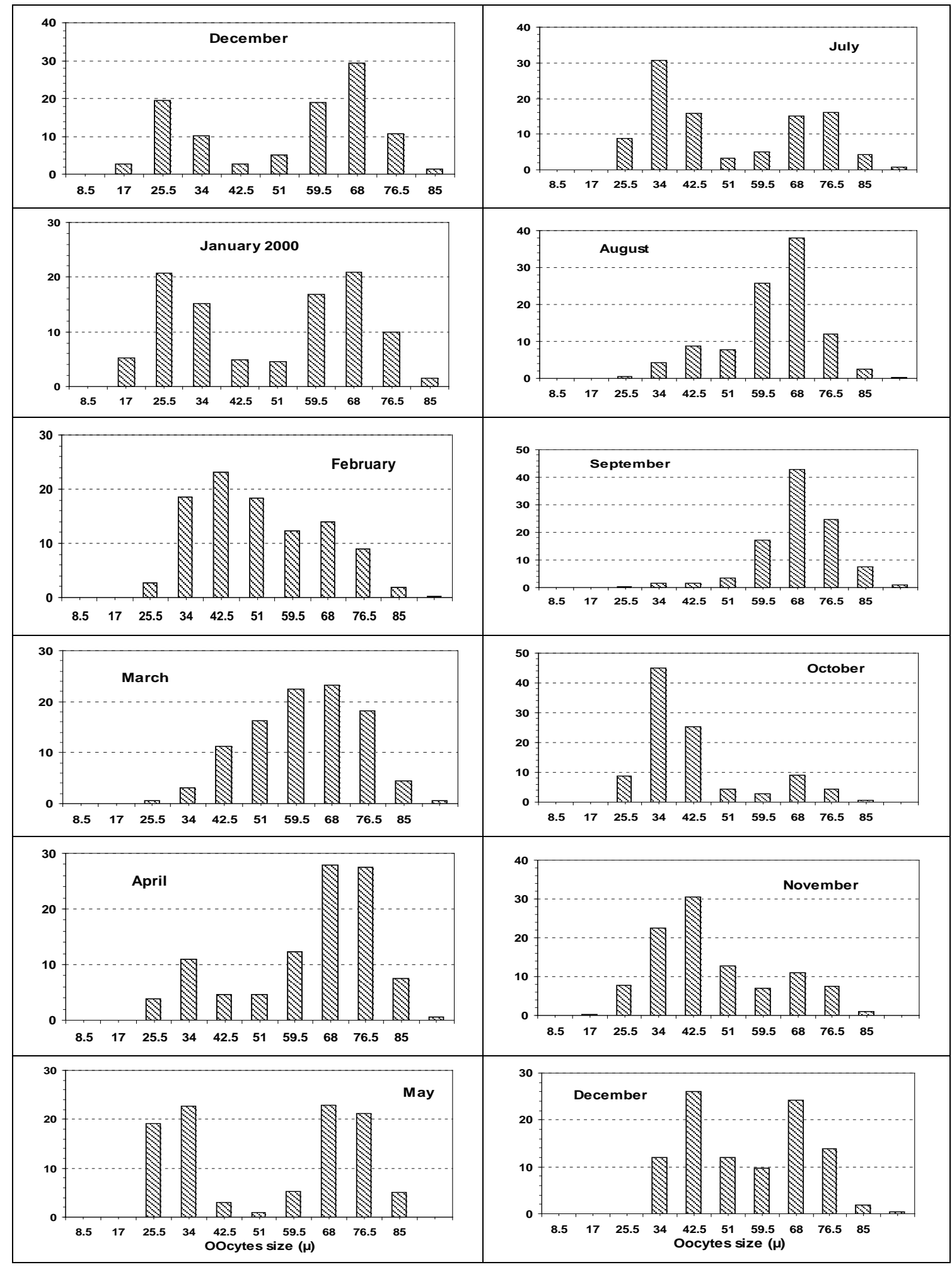

Fig. 3: Oocytes size frequency distribution of Astropecten polyacanthus from Great Bitter Lake.

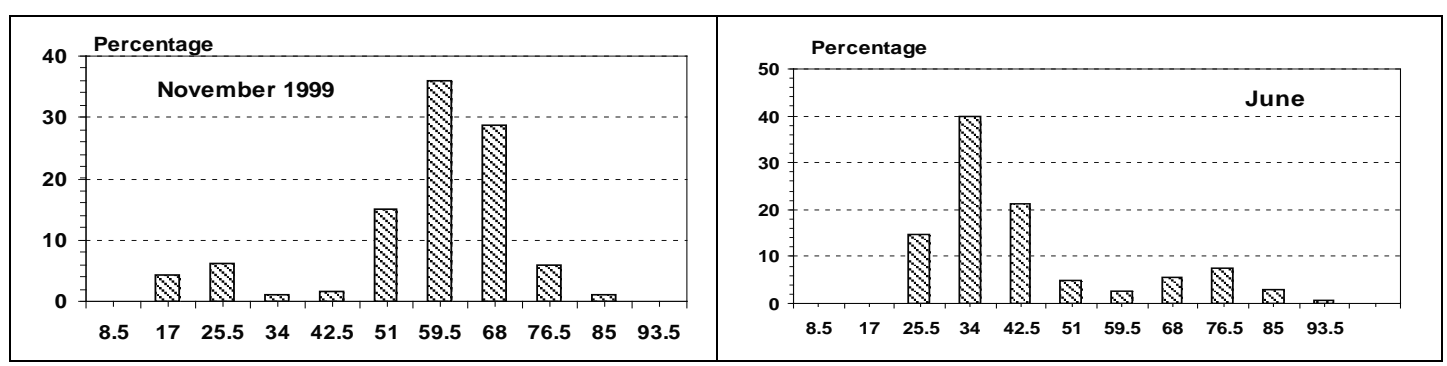




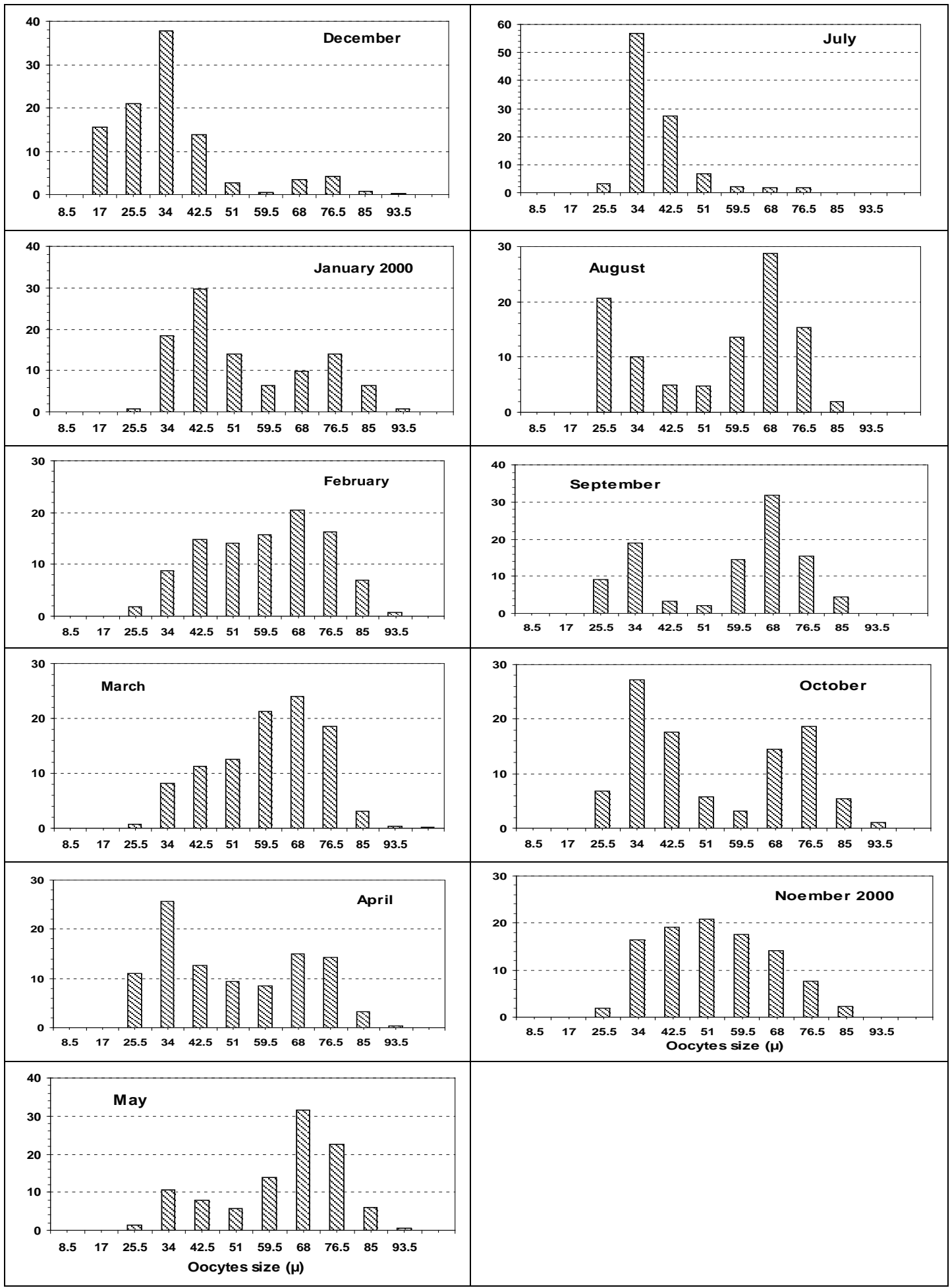

Fig. 4: Oocytes size frequency distribution of Astropecten polyacanthus from Lake Timsah.

\section{ARABIC SUMMARY}

إستراتيجية التكاثر لنجم البحر الثائع/سترويكتن بولى اكانسس (شوكيات الجلا: النجمانيات) من بحيرات قناة 


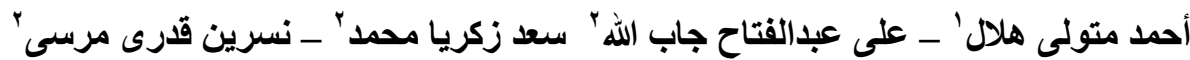

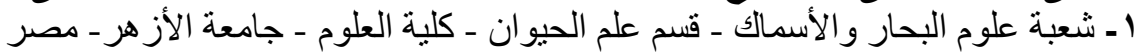

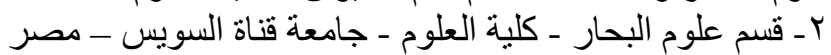

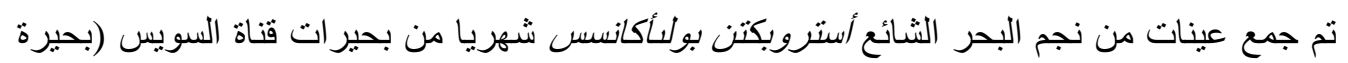

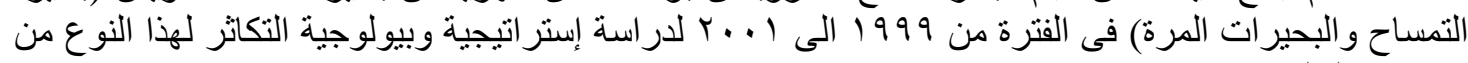

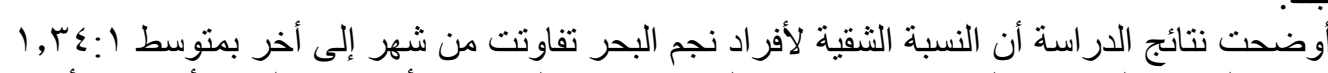

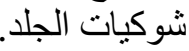

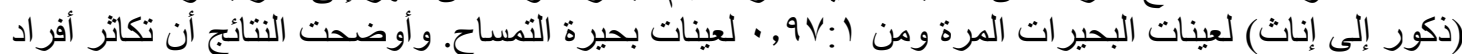

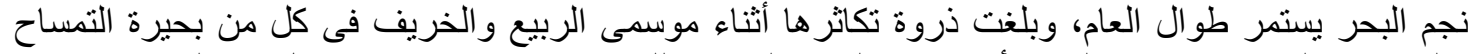

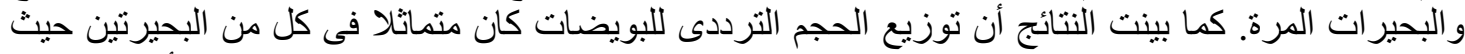

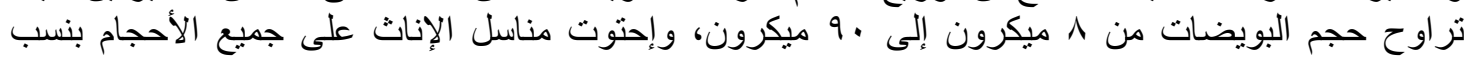
متفاوتة.

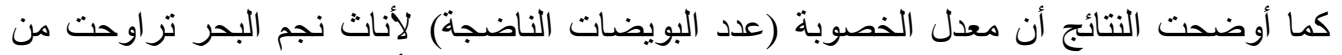

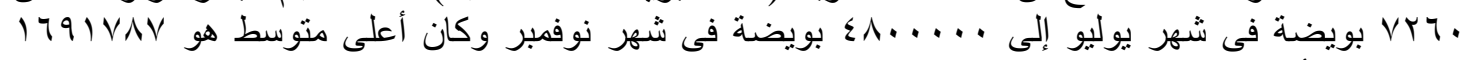

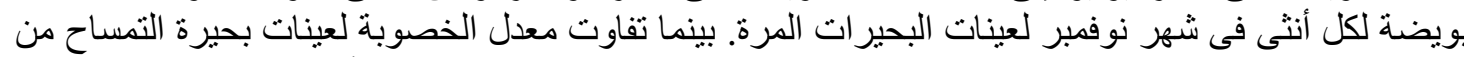

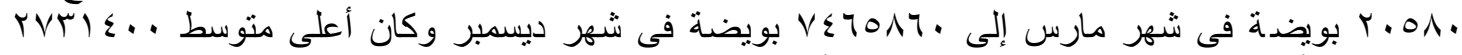

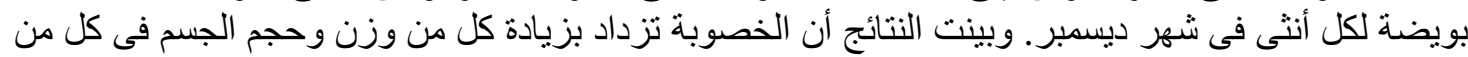

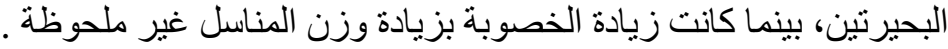

